マルチ抗原検出マイクロチップ用レーザ表面処理技術の開発

\title{
Laser Surface Treatment of Plastics for a Single-Channel Multiple Immunoassays Chip
}

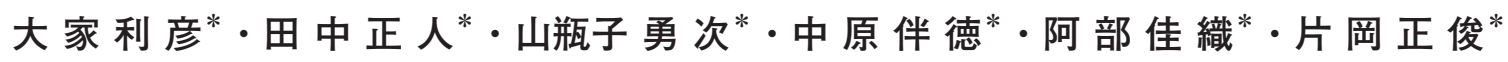 \\ Toshihiko OOIE, Masato TANAKA, Yuji YAMACHOSHI, Tomonori NAKAHARA, \\ Kaori ABE and Masatoshi KATAOKA
}

(Received March 9, 2011)

\begin{abstract}
A novel micro immunoassay chip for detecting biomarkers in blood plasma has been developed by using an injector-based antibody immobilization. Since multiple detectors were made in a single channel, the chip was able to detect various biomarkers simultaneously. UV Laser processing of the substrate was performed to enhance immobilization of the antibody. In P1CP, which is a biomarker for osteoporosis, this simple plastic chip requires only 1 micro liter per lane of blood plasma and 30 min of reaction time, one twentieth the sample volume required for the ELISA-kit and six times the through put.
\end{abstract}

Key Words: Microfluidic, Microchannel, Cover Film, Injection Mold, ArF Excimer Laser, Injector, Inkjet, PMMA, COC, Biomarker, Antibody, Antigen

\section{1. 緒言}

ELISA(Enzyme-Linked ImmunoSorbent Assay) 法は極微量 の抗体、あるいは抗原の濃度を検出するのに用いられる。 特異性の高い抗原抗体反応を利用し、酵素反応に基づく発 色・発光等を測定することで、多種のタンパク質が混在す る生体試料中から特定のタンパク質を検出・定量すること ができるが、マイクロプレートを用いる血液検査では、1 項目あたり $20 \sim 100 \mu \mathrm{l}$ のサンプルが必要で、測定に数時 間を要する。医療現場や在宅でのその場診断、すなわち POCT (Point Of Care Testing) ${ }^{1)}$ 用途では、必要サンプル量の 低減と測定時間の短縮が不可欠である。我々は、インジェ クタを用いて、プラスチック基板上のマイクロ流路底部に 抗体溶液を吐出 ·固定化する独自の技術を用いて、マイク ロ流路内でサンドイッチ ELISA を実現し、極微量サンプル での抗原検出に成功した ${ }^{2-3)}$ 。これは、大型の分析装置を小 型化しょうとする Micro Total Analysis System (micro-TAS) ${ }^{4-10)}$ の流れとは異なったアプローチであり、低コスト化が容易 な点が特徵である。本手法における、抗体固定化面の表 面処理としては、市販のマイクロプレートと同じポリマー コーティングを用いているが、ウェットプロセスであるこ とから、(1)溝底面エッジ部の処理が不均一となりやすい、(2) 処理に時間を要する等の課題がある。本研究では、UVレー ザ照射による表面処理で、これらの課題を解決することを 目的とする。

\section{2. 実験方法}

\section{1 基板の加工及び表面処理方法}

本研究においては、主として(1) 環状ポリオレフィン （COC）射出成形基板に市販マイクロプレートと同一のポ リマーコーティングを行ったもの（住友ベークライト(株製、 BS-X2321：特注品、厚さ $0.7 \mathrm{~mm}$ ) ならびに、(2)これと同 一形状でコーティングのないものを用いた。共に、基板表 面には幅 $300 \mu \mathrm{m}$ 、深さ $100 \mu \mathrm{m}$ 、長さ $60 \mathrm{~mm}$ の直線流路が 4 本あり、その両端は直径 $1 \mathrm{~mm}$ の貫通孔がある（Fig.1）。 また、COCに加えて、基板材料に関する比較検討用とし て (3) 射出成形 PMMA ${ }^{11-12)}$ 基板でも実験を行った。なお、

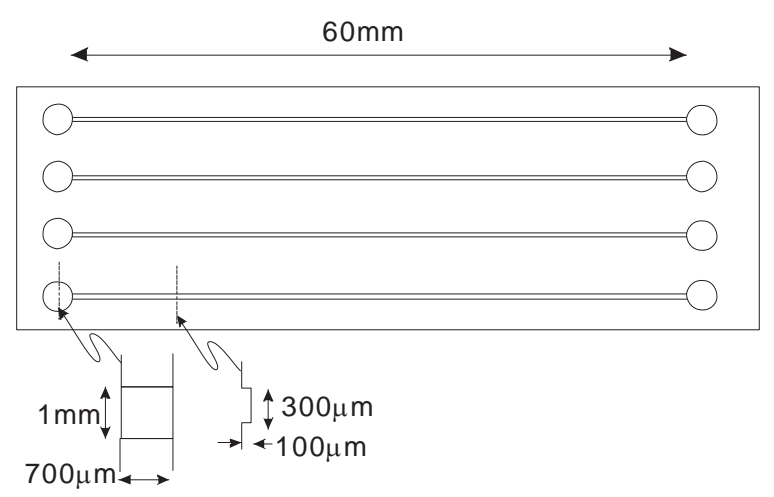

Fig.1 Injection molded base-chip for on-chip detection of P1CP.

* 独)産業技術総合研究所四国センター健康工学研究部門（广 761-0395 香川県高松市林町 2217-14）

National Institute of Advanced Industrial Science and Technology, Health Research Institute

(2217-14 Hayashi-cho, Takamatsu, Kagawa 761-0395 Japan) 


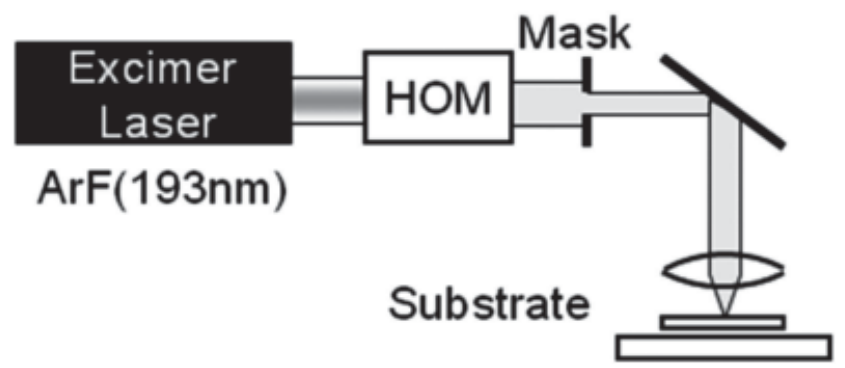

Fig.2 Schamatic diagram of laser system used for the modification of chip surface.

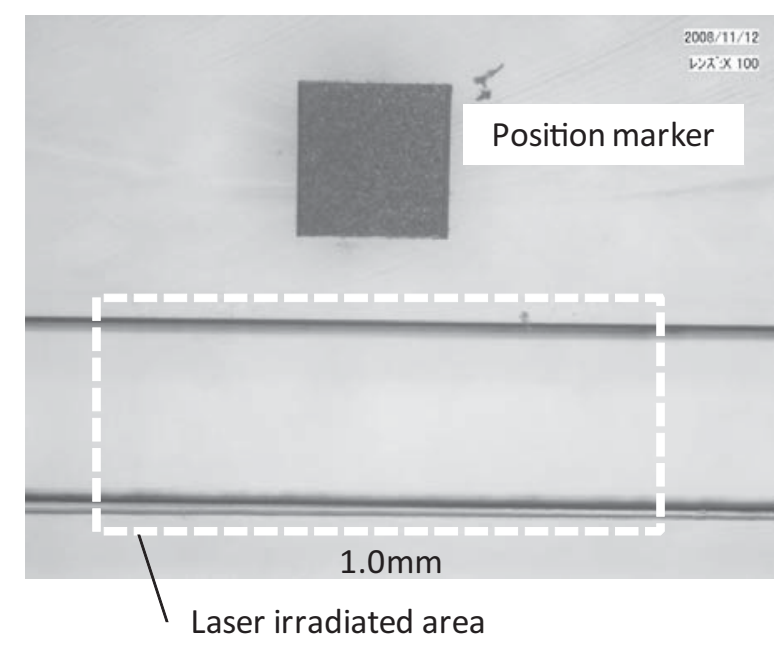

Fig.3 Laser irradiation area on the bottom surface of microgroove.

PMMA 基板については、入手可能な基板の制約から流路深 さは COC 基板と同じ $100 \mu \mathrm{m}$ だが、流路幅が $500 \mu \mathrm{m}$ と若 干広めとなっている。

Fig.2 にレーザ照射用光学系の構成を示す。発振器からの 出力ビームはホモジナイザで強度を均一化した後、マスク で中央部を切り出し、倍率 $1 / 10$ の縮小光学系で基板上の流 路底面に結像させた。レーザ照射範囲はFig.3に示すよう に、流路中の抗体固定化部位を中心に、幅 $350 \mu \mathrm{m} \times$ 長さ 1 $\mathrm{mm}$ の領域とした。なお、Fig.3の上部にある正方形部は抗 体吐出の際の位置決めに用いるポジションマーカである。

後述するように、市販のポリマーコーティングを施した 基板 (1) を基準として、(2) 及び (3)の基板について、その ままで抗体固定化を行った場合と、所定のフルエンスの ArF エキシマレーザ照射をした後で抗体を固定化した場合 について、抗原検出能力を比較した。

\section{2 抗体固定化と流路化カバー}

本実験では I 型プロコラーゲンC 末端プロペプチド $(\mathrm{P} 1 \mathrm{CP})^{13-14)}$ 用モノクローナル抗体（タカラバイオ(株製）を 固定化液（住友ベークライト(株)製）で $0.1 \mathrm{mg} / \mathrm{ml}$ に希釈し

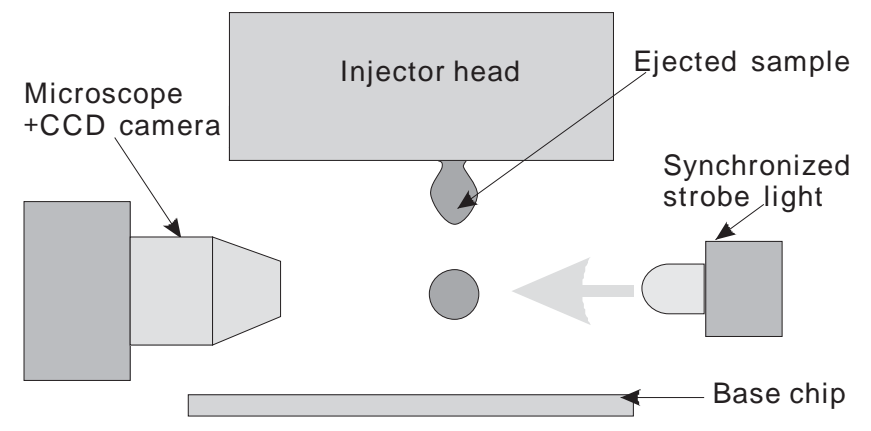

Fig.4 Imaging of ejected droplets using a CCD camera equipped with synchronized strobe light.

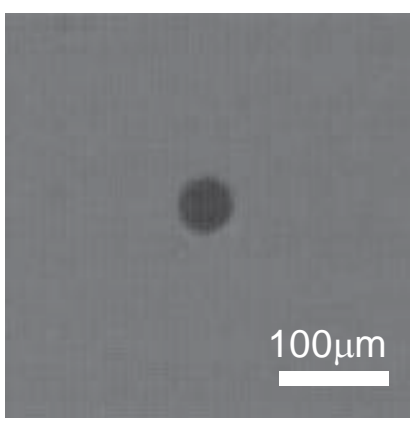

(a) $\mathrm{P} 1 \mathrm{CP}$

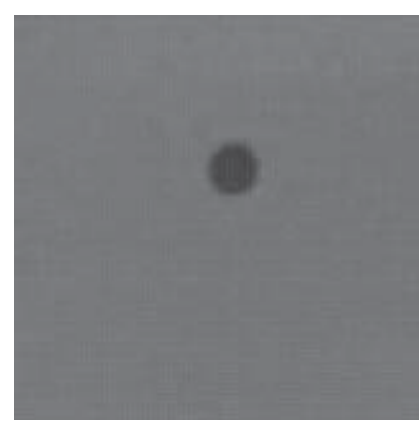

(b) H-FABP
Fig.5 Images of ejected droplets. Antibody solution for P1CP, (a) and for H-FABP, (b).

た後、圧電駆動型インジェクタ（クラスターテクノロジー (株製、パルスインジェクター）を用いて、チップ上のマイ クロ流路底面に一流路あたり複数点に対して吐出、固定化 を行った。また、抗ヒト心臓由来脂肪酸結合蛋白 (H-FABP) 抗体を同じ流路内に抗 P1CP 抗体と同様に吐出・固定化し、 P1CP 検出におけるネガティブコントロールとして用いた。 吐出・固定化された抗体溶液量は、Fig.4に示すように、吐 出液滴の顕微鏡拡大像をストロボ撮影し、直径と液滴数に より算出した。P1CP ならびに H-FABP の吐出液滴画像の例 を Fig.5に示す。この例ではいずれも液滴の直径は $56 \mu \mathrm{m}$ 、 体積は $92 \mathrm{pl}$ である。固定化の際には 50 ～ 200 回の吐出を 行っており、1点あたりの抗体溶液量は $4.6 〜 18.4 \mathrm{nl}$ となる。

流路底面に抗体を吐出・固定化した後は粘着剂塗布フィ ルム（東洋インキ製造(制製、特注品）により、流路をカバー し、マイクロ溝を流路、両端の貫通孔をそれぞれ試料導入・ 排出ポートとする評価用チップを構成した。

\section{3 抗原検出能の評価}

評価用チップのフィルム面を下とし、マイクロプレート でのサンドイッチ ELISA に準じた下記のプロトコルにより P1CP の検出を行った。 
マルチ抗原検出マイクロチップ用レーザ表面処理技術の開発（大家・田中・山瓶子・中原・阿部・片岡）

(1) 室温で 4 時間放置し、自然乾燥

(2) 洗浄液導入

(3) ブロッキング処理（住友ベークライト(株)製試薬）

(4) 洗浄液導入

(5) P1CP 溶液とペルオキシターゼ標識化 2 次抗体の混合液 を導入

(6) 30 分間放置

(7) 化学発光基質導入

(8) 発光強度測定

発光強度の測定には、冷却 CCD カメラによる画像解析 装置（GEヘルスケア(株製、LAS4010）を用いた。

\section{3. 実験結果と考察}

3.1 レーザ照射に伴う流路底面の変化

COC マイクロ流路に対し種々のフルエンスで1パルスの レーザ照射を行った後の流路外観をFig.6に示す。0.44 J/ $\mathrm{cm}^{2}$ では外観上の変化が見られないが、 $0.88 \mathrm{~J} / \mathrm{cm}^{2}$ では、周 辺部の透明度が低下しはじめ、フルエンスの上昇に伴い中 央部に広がっている。顕微鏡観察の結果、透明度低下領域 では表面での微細凹凸の形成と微粒子付着が認められた。 COC、PMMA ともにレーザ照射基板については、蒸留水 を用いた超音波洗浄を行った後に抗体の固定化を行ってい る。

\subsection{COC 基板における固定化と抗原検出}

(1) 未処理、(2) フルエンス $0.44 \mathrm{~J} / \mathrm{cm}^{2}$ の 1 パルス照射に よるレーザ処理、(3) ポリマーコートの 3 種類の COC 基板 に対し、それぞれ、50滴 $(4.6 \mathrm{nl})$ の吐出を行った際の付着

(a) $0.44 \mathrm{~J} / \mathrm{cm}^{2}$

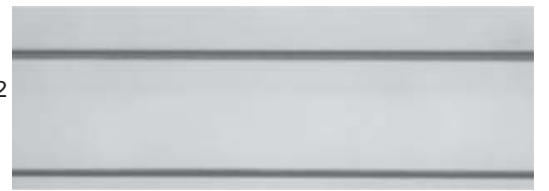

(b) $0.88 \mathrm{~J} / \mathrm{cm}^{2}$

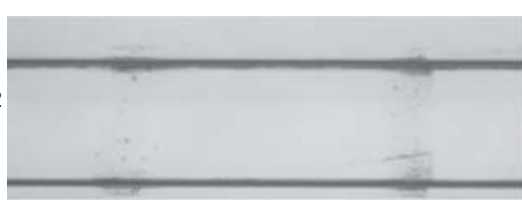

(c) $1.32 \mathrm{~J} / \mathrm{cm}^{2}$

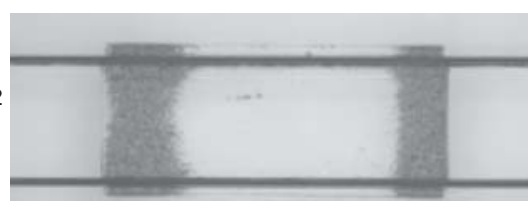

(d) $1.76 \mathrm{~J} / \mathrm{cm}^{2}$

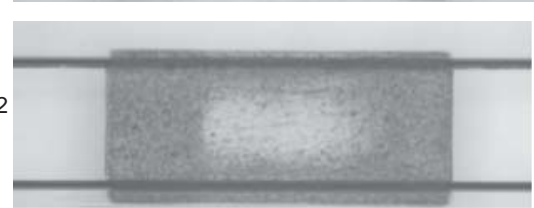

Fig.6 Photographs of microgrooves after laser irradiation at various fluences.
液滴の外観を Fig.7 に示す。

ポリマーコート面ではP1CP の液滴が流路幅一杯に広 がっているのに対し、H-FABP は小さなドット状となって おり、ポリマーコート面に対する濡れ性に大きな違いが見 られる。これに対して、未処理面では 2 種類の抗体溶液で 差は見られない。レーザ処理面と未処理面の間でも差違は 認められない。

それぞれ固定化した抗体について、640 ng/ml の P1CP 溶 液を導入し、さらに発光強度測定段階に至った際の画像が Fig.8 である。図中には 3 種類の基板それぞれについて、ネ ガティブコントロールとしての H-FABP 検出点が 1 カ所 (左 側の四角内）と P 1 CP 検出点が 4 力所存在する。それぞれ 検出点の信号を積分し、その数值と標準偏差を求めた結果

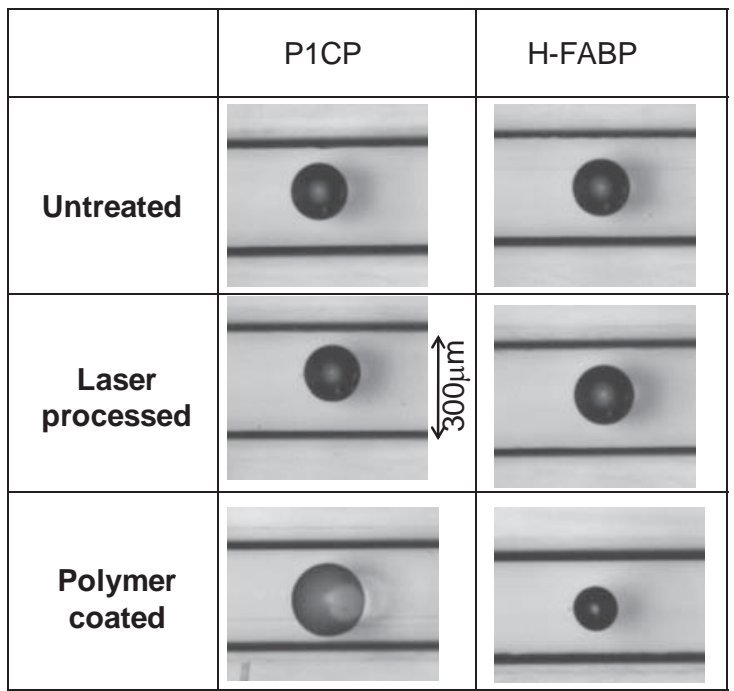

Fig.7 Photographs of ejected droplets on the bottom surface of microgrooves.

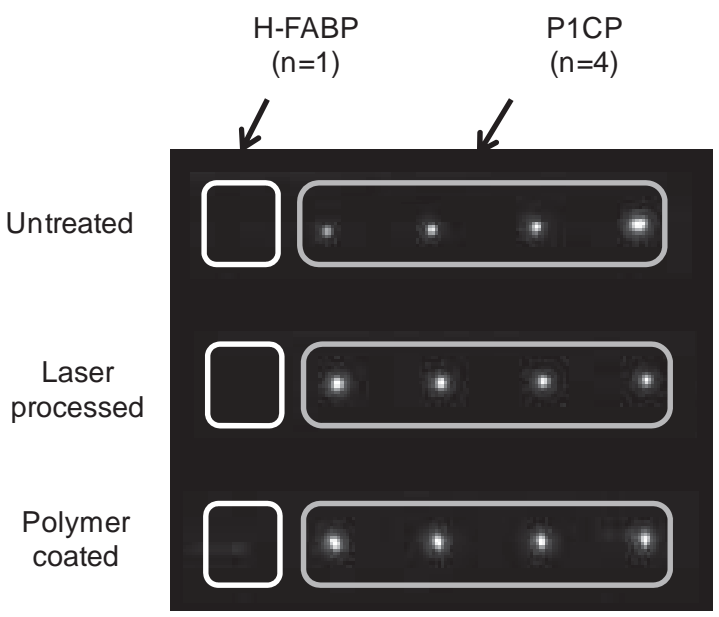

Fig.8 An image of chemiluminescence from detection dots with a P1CP antigen solution of $640 \mathrm{ng} / \mathrm{ml}$ in density. Exposure time was $20 \mathrm{~min}$. 
をFig.9に示す。フルエンスわずか $0.44 \mathrm{~J} / \mathrm{cm}^{2}$ と低強度のレー ザを 1 パルス照射するだけで、未処理面と比べて P1CP 検 出感度の向上が認められ、信号のばらつきも抑制されるこ とがわかった。

検出感度向上に向け、吐出液滴数を $200(18.4 \mathrm{nl})$ として、 種々のレーザフルエンスでの処理面に対し抗体溶液の吐出 を行った時の液滴画像を Fig.10に示す。200 滴の吐出では 液滴が広がりやすいポリマーコート面の場合、ほとんどの ケースで吐出中に液滴が壁面と底面のエッジ部に移行して しまい、安定した固定化が難しい。これに対し、前述のよ うにレーザ照射面では液滴の広がりが小さく、壁面に付着 しにくいため、比較的安定した固定化が可能であった。レー ザフルエンスが $1.76 \mathrm{~J} / \mathrm{cm}^{2}$ まで増大しても、付着抗体液滴 の大きさ、形状は未照射面とほとんど差が見られない。こ れに対して、P1CP 検出信号については、レーザフルエン スの増大に伴って数值が上昇し、同時にばらつきが縮小す

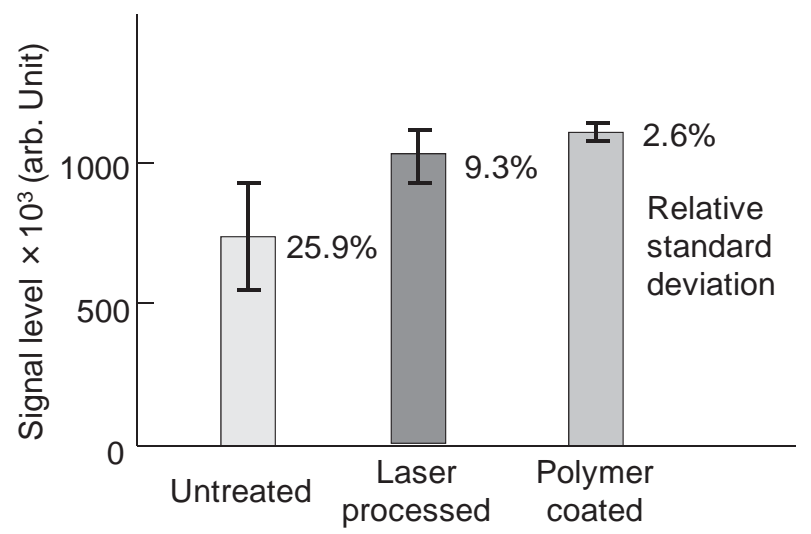

Fig.9 Comparison of signal level and relative standard deviation of each chip.
るという結果が得られた。 $1.76 \mathrm{~J} / \mathrm{cm}^{2}$ ではほぼポリマーコー トに匹敵する信号レベルとなっている。

\subsection{PMMA 基板における固定化と抗原検出}

$\mathrm{ArF}$ エキシマレーザ照射による表面処理ののち抗体を吐 出・固定化することで COC 表面での P1CP 検出感度が向上 することがわかったため、COC と比べてょり親水性の樹脂 である PMMA について、同様の検討を行った。PMMAで はCOCよりも低いレーザフルエンスで表面の除去が起こ るため、レーザフルエンスは COC を用いた実験での最小 值よりもさらに低い $0.36 \mathrm{~J} / \mathrm{cm}^{2}$ とした。

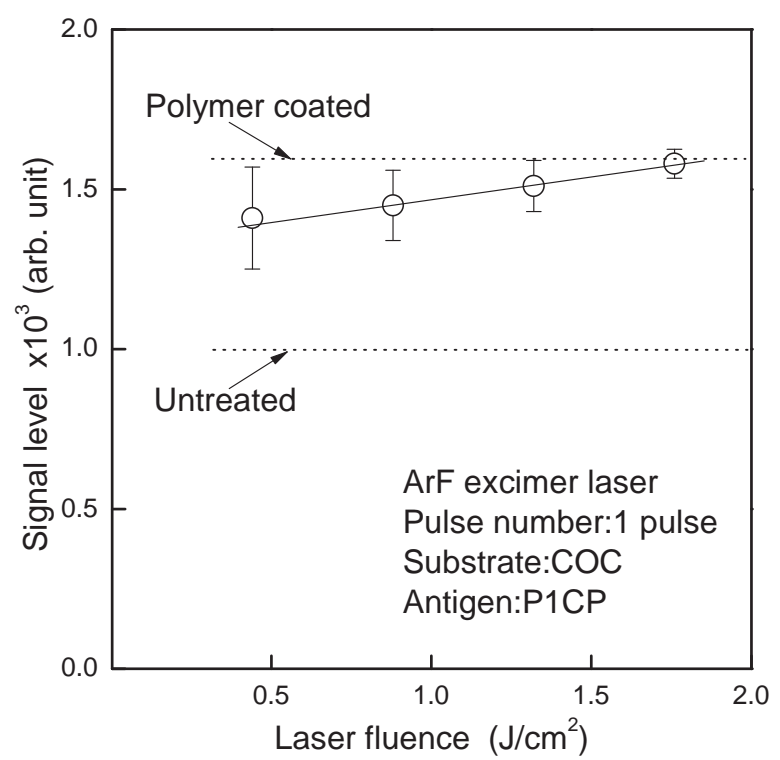

Fig.11 Effect of laser fluence on signal level in P1CP detection by using sandwich ELISA method in microchannel.

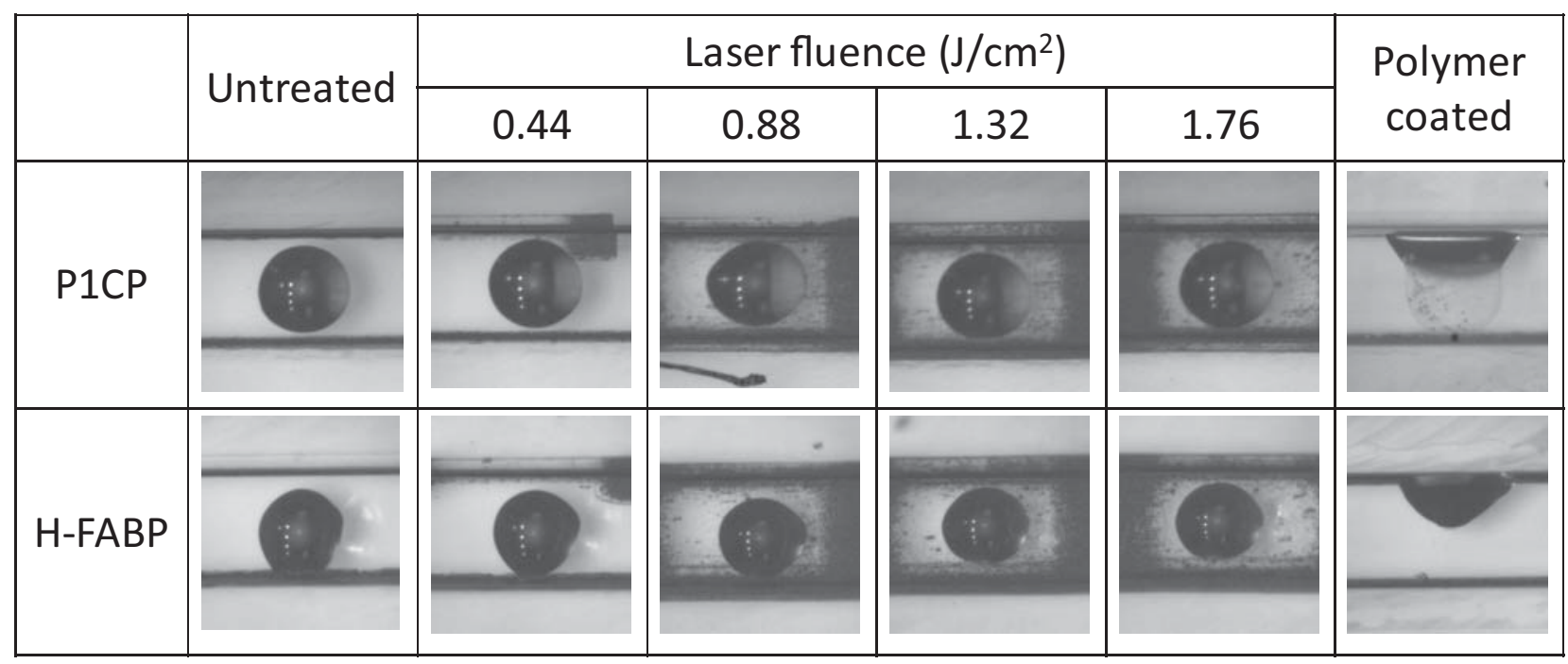

Fig.10 Antibody dots for P1CP and H-FABP on untreated, laser irradiated and polymer coated COC chip. 


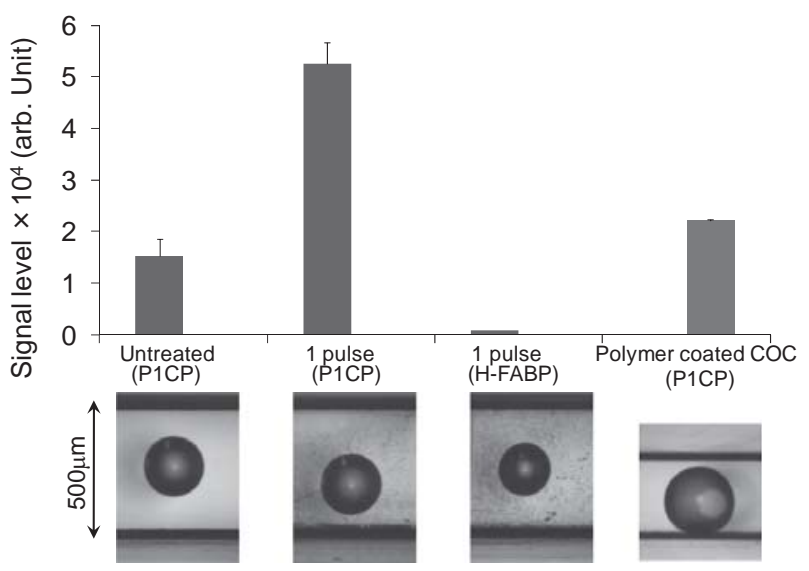

Fig.12 Images of immobilized antibody on the bottom surface and their signal levels in P1CP detection.

Fig.12 は PMMA 流路底面での抗体液滴画像と P1CP 抗原 $(640 \mathrm{ng} / \mathrm{ml})$ 導入時の検出信号強度をポリマーコート COC と比較して示している。ポリマーコート面と比べて未処理 面とレーザ照射面の広がりが小さいこと、未処理面とレー ザ照射面で広がりの差が認められないことは COC の場合 と同様であるが、レーザ照射面での抗 H-FABP 抗体の広が りが小さめである点が異なっている。信号強度はレーザ照 射により 3 倍以上に向上し、大幅な感度向上が確認できた。 実験のために用意できたチップの流路幅の違いから、反応 に関与する $\mathrm{P} 1 \mathrm{CP}$ ならびに 2 次抗体の数が異なるためポリ マーコーティングとの直接比較はできないが、流路幅の比 （1.7）以上の信号レベルが得られており、COCの場合と同様、 ポリマーコーティングと同等以上の効果があるものと推察 される。

3.4 検出感度向上因子

同一抗体による P1CP 検出感度に関わる因子としては、

(1) 抗体固定化密度の向上

(2) 抗体固定化面積の拡大

(3) 抗体認識部位の配向性

(4) 抗体の活性度

(5) 非特異吸着によるバックグラウンド上昇

といったものがあるが、このうち、(5)については、実際の 発光信号測定においてレーザ照射に伴う変化は認められな い。同一条件での吐出固定化で、かつ物理吸着であること から (4) も除外される。特定の官能基を導入している訳で はないため、(3)の可能性も低い。レーザフルエンス増大時 の表面形状の変化との対応から (2)の影響は少なからず存 在するが、光学的に変化がない $0.44 \mathrm{~J} / \mathrm{cm}^{2}$ でも明確な効果 が得られていることから、主要因とは言えない。

残るは (1)の固定化密度の向上である。ArF ならびに $\mathrm{KrF}$ エキシマレーザの照射に伴い、分子鎖が切断されて、溶媒

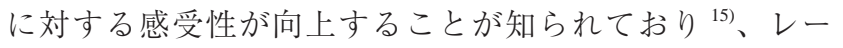

ザ照射により基板表面に露出した分子鎖末端が増えること で、抗体の物理吸着サイトが増えたのではないかと推察し ている。

\section{4. 結 論}

本研究では、インジェクタを用いてマイクロ流路内に抗 体を直接固定化して抗原を検出する新しい流路型マイクロ チップに向け、レーザ表面処理を提案し、P1CP 濃度測定チッ プにおけるその効果を市販のマイクロプレートに使われる ポリマーコーティングと比較した。

疎水性の COC、親水性の PMMA いずれについても波長 $193 \mathrm{~nm}$ の ArF エキシマレーザを照射することで P1CP 濃度 測定チップの感度はポリマーコーティング時と同等あるい はそれ以上に向上した。必要なレーザフルエンスは非常に 低く、1パルスの照射で済むため高スループットが実現で きる。ドライプロセスであることから、流路形状による処 理の偏りが生じにくく、狭隘部での表面張力の影響がない など、流路型マイクロチップに適した表面処理法である。

\section{引用文献}

1) E. Eteshola, D. Leckband: Sensors and Actuators B-Chemical, 72, (2001) 129

2) M. Kataoka, S. Yatsushiro, S. Yamamura, M. Tanaka, T. Ooie: Synthesiology, 3(1), (2010)43.

3) 片岡正俊、八代聖基、日野真美、木戸淳一、板東美香、大家利彦: 歯学展望、113(4), (2009)654.

4) B. Graß, R. Hergenröder, A. Neyer and D. Siepe: J. Sep. Sci. 25, (2002) 135.

5) J. Wang, M. Pumera, M. P. Chatrathi, A. Escarpa, R. Konrad, A. Griebel, W. Dörner and H. Löwe: Electrophoresis 23, (2002) 596.

6) R. M. Mc Cormick, R. J. Nelson, M. G. Alonso-Amigo, D. J. Benvegnu and H. H. Hooper: Anal. Chem. 69, (1997)2626.

7) X. M. Zhou, Z. P. Dai, X. Liu, Y. Luo, H. Wang and B. C. Lin: J. Sep. Sci. 28, (2005) 225.

8) J. Brandrup and E. H. Immergut, Polymer Handbook 3rd ed. ISBN 0-471-812447-7, V/77.

9) B. Crist, M. E. Marhic, G. Raviv and M. Epstein: J. Appl. Phys., 51(2), (1980) 1160.

10) K. Shimura, Y. Koyama, T. Kitamori: Molecular \& Cellular Proteomics, 5(10), (2006)S311.

11) E. Tamaki, A. Hibara, H. Kim, M. Tokeshi, T. Kitamori: J. Chromatography A. 1137(2), (2006)256.

12) A. Oki, M. Takai, H. Ogawa, Y. Takamura, T. Fukasawa, J. Kikuchi, Y. Ito, T. Ichiki and Y. Horiike: J. Appl. Phys 42, (2003)3722.

13) Taubman, M.B., Goldberg, B., Sherr, C. J.: Radioimmunoassay for human procollagen, Science, 186, (1974) 1115.

14) Savolainen, E. R., Goldberg, B., Leo, M. A., et al., Alcoholism: Chemical and Experimental Research, 8, (1984) 384.

15) H. Miyashita, T. Ooie, T. Nakahara, Y. Baba: J. Micronano Eng., 3(2), (2008)88. 